\title{
Current Issues and Specific Features of Livestock Development
}

\author{
Ksenia Yu. Voloshenko \\ Natalia F. Ogneva* \\ Immanuel Kant Baltic Federal University, Russian Federation \\ *Corresponding Email: natashafedorovna@mail.ru
}

Doi:10.5901/mjss.2015.v6n6s7p248

\begin{abstract}
The article deals with the development of livestock in the Kaliningrad region in 2000-2014. It analyses dynamics of main indicators, the state of agricultural machinery supply and food reserve. Current problems in livestock farming in the region are brought to light. Primary trends of livestock sustainable development in the region are defined in the light of recent trends in the global economy.
\end{abstract}

Keywords: agriculture, livestock farming, sector, long-term development, food security

\section{Introduction}

The issues of support and development of agricultural industry are currently important for the Kaliningrad region as well as for the greater part of the subjects of the Russian Federation and regions of other countries. The main objective here is to better satisfy consumer demand in foodstuffs. The main reasons are an increase in agricultural produce consumption, as a result of the improved standards of living and the necessity to provide food security in Russian regions in the face of the changing geopolitical environment. Moreover, agriculture is a vital sector of the regional economy, creating jobs and encouraging innovation. It also develops new forms of integration and cooperation between the private and the public sectors. It generates the demand for products of related industries (mineral fertilizers, machinery and equipment, irrigation engineering, gene engineering and biotechnologies, robotics and electronics and others).

Livestock farming in the Kaliningrad region is now becoming ever more relevant as long as an array of sanctions against Russia was imposed. Being a priority area of the agricultural industry, livestock provides satisfaction of evergrowing food demands. Qualitative changes in the farming industry boost agriculture as a whole and the regional agricultural market in particular.

\section{Indexes of Livestock Development}

Conditions and factors of livestock development in the Kaliningrad region differ from those in the majority of Russian regions. Among the advantages, there are climatic conditions of the region (a longer vegetation season and mild winters) as well as economic factors (the use of all forms of transport and cooperation with the EU countries).

In recent years livestock production volumes in all categories of farmsteads have been improving (Fig. 1). 


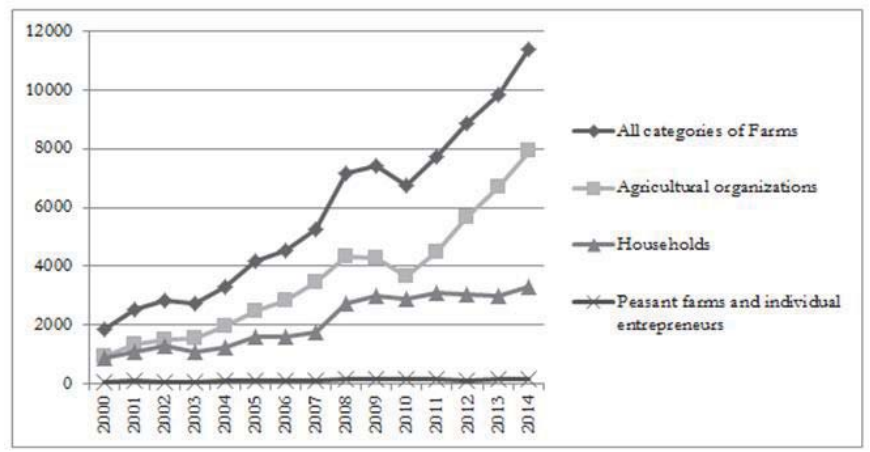

Four curves of the diagram are (from top to bottom): All categories of farms; Agricultural organizations, Households, Peasant farms and individual entrepreneurs.

Figure 1. Livestock production in all categories of farmsteads (current prices for the year stated, million rubles)

Source: calculated on the basis of (Federal State Statistics Service in the Kaliningrad region, 2005-2015)

Gross agricultural production output of the livestock farming has gradually been growing during 2000-2009. Since 2010 a rapid growth has been observed. This is due to the application of specific policies and state programs providing support to the agricultural industry.

During the last 15 years, the output of the basic livestock production has been decreasing, with occasional periods of positive growth, though.

Production of cattle and poultry for slaughter has grown (2.3 times in 2014 as compared to 2000). However, other livestock production has decreased (production of milk - 1,4 times down, eggs - by 11,9\% and wool - 22,6 \%). In 2014, the growth of cattle, poultry and milk production was observed (by 105,8 \% and 105,0\% respectively) (Fig. 2).

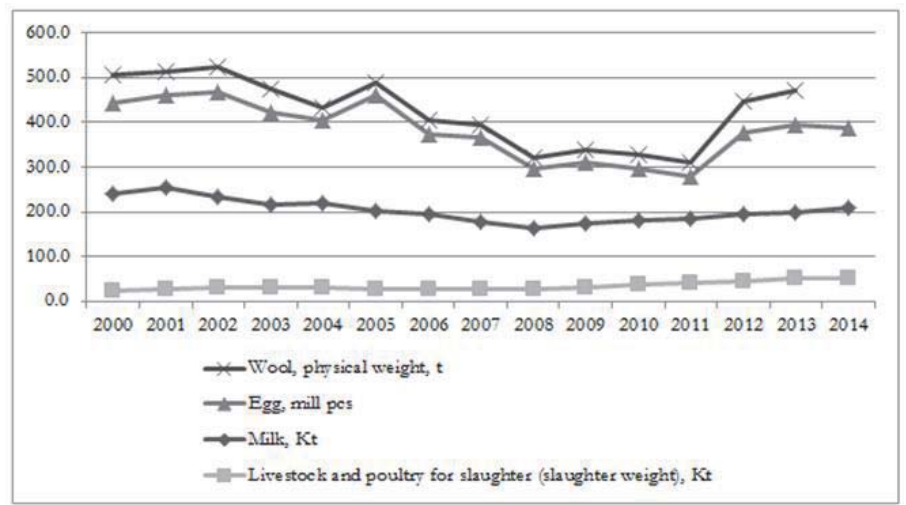

Four curves of the diagram are (from top to bottom): Wool (tons); Eggs (mill pcs); Milk (Kt); Livestock and poultry for slaughter (Kt).

Figure 2. The output of basic livestock products in all categories of farmsteads in 2000-2014.

Source: calculated on the basis of (Federal State Statistics Service in the Kaliningrad region, 2005-2015)

The increase in the livestock production has led to a gradual enlargement of farms and their better integration, leading to the reduction in the number of privately owned and individual peasant farms in all categories of farmsteads. Most notably the decrease in the number of farms is seen in the production of cattle and poultry for slaughter. In 2014, the proportion of private cattle and poultry farms dropped from $45.5 \%$ to $11.3 \%$ and the proportion of peasant farms households from 4.7 $\%$ to $0.6 \%$ compare to 2000 ; dairy farms - from 56.3 to $41.0 \%$ and from $6.0 \%$ to $3.2 \%$ respectively. In $2010-2011$, in the production of eggs the proportion of individual farms rose to 41.6 and $51.6 \%$ respectively, though this increase was witnessing an overall drop in eggs production in the region. 
The number of basic types of farmed animals has changed within the analyzed period of time. The number of large cattle has increased during the last three years, however, it is still 1.6 times lower than the number of pigs, sheep and goats -2.6 times and poultry -1.7 times lower compared with the year 2000. In general, the number of large cattle has decreased in the overall number of cattle and poultry for slaughter (Fig. 3).

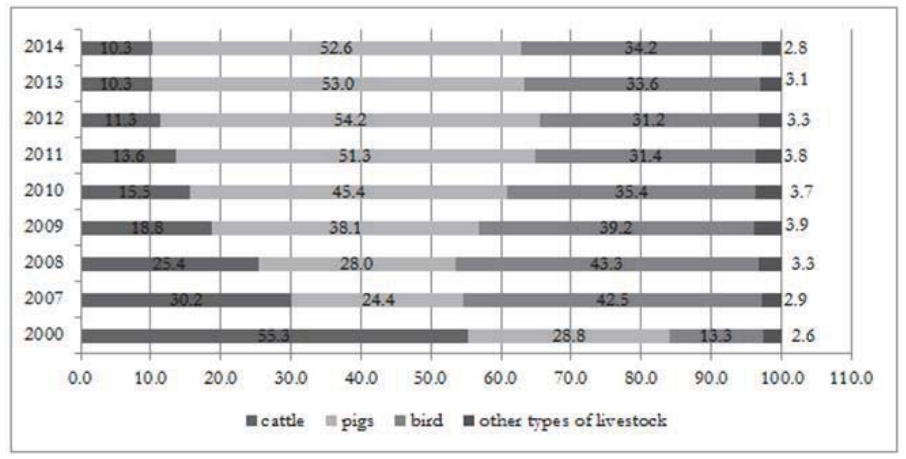

Figure 3. Number of cattle and poultry for slaughter (slaughter weight, in all categories of farmsteads, \%), 2000-2014. Source: (Federal State Statistics Service in the Kaliningrad region, 2015)

Meat and dairy farming traditionally plays the leading role in the agricultural industry of the Kaliningrad region. However, the number of cows in the overall number of large cattle in all categories of the Kaliningrad region farmsteads dropped from 170.1 to 46. 8 thousand (a 3.6-fold decrease) in 2014 compare to 1990. The main reason for the decrease was the same as for other regions of Russia - an imbalance of the national economy sectors due to Russia's economy transition to the market-oriented system and private farming with its prevailing number of corporate and private farmsteads. Later, the number of cattle was affected by low profitability of agricultural produce, low productivity in the region and high prices of cattle fodder and medicine, caused by the fact that the Kaliningrad region is an exclave. It is worth mentioning, that the decrease in the number of cows mainly concerned corporate farms. At the same time, the number of cattle in private farms had not changed until 2001. The largest decrease in the number of cattle in private farms (more dramatic than in corporate and individual peasant farms), was noted in 2004-2007. It happened for a number of reasons. Firstly, low profitability of agricultural produce and difficulties in its sales, and transition to the market economy led to the decrease in the number of cattle and agricultural output. For the last ten years, the Kaliningrad region has had an unreasonably low purchase price for milk. A change in the general price level and the profit from dairy sales are interrelated. With the current milk price, the production of milk at private farms is unprofitable. Secondly, very low productivity of cattle farming and unsatisfactory state of breeding have led to a $50 \%$ decrease in the production of milk especially at private farms. Thirdly, the competitiveness of dairy farming at the regional market is limited by price control and regulated conditions of raw milk supply and milk sales. In general, the analysis of livestock development indexes shows that the recent years saw efforts aimed at increasing cattle productivity, particularly the introduction of modern agro-technologies and application of financial measures and regulations. Providing producers are effective and there is a governmental support, the livestock crisis can be overcome.

\section{Fodder Supply}

According to agricultural producers, cattle fodder is a significant livestock development constraint in the Kaliningrad region. Fodder supply in the region depends on the conditions and productivity of pastures.

Once well-kept and cultivated, Kaliningrad pastures are now overgrown with weeds and are not suitable for cattle grazing. Moreover, pastures may be populated with ticks. Tick bites are dangerous for cows and lead to diseases in livestock thus decreasing milk yield. One of the main problems for private farms is fodder conservation, due to the lack of equipment individual farms cannot conserve fodder. For instance, one needs to sell more than one ton of milk to purchase enough fodder for one cow in the Slavsk district in the Kaliningrad region. Apart from hay used for feeding, large cattle farms have to buy mixed feed and the price of one kilogram of it is 1.3 higher than that of one kilogram of milk. As a result, only one fourth of private farms add the necessary concentrated additives to the feed of large cattle 
(Federal State Statistics Service in the Kaliningrad region, 2007).

The biggest share of pastures (50\%) is used for large cattle. In general, there are 30 hundredweights of fodder units used in Russia per one head of livestock (in 2013, there used to be 31.2 in the Kaliningrad region), while in livestock in the developed countries, there are 40-45 hundredweights. Only $30 \%$ of fodder is supplied to the Kaliningrad region, the remaining $70 \%$ are bought in Russia or in the neighboring countries. In these conditions many large enterprises are forced to grow fodder themselves. Among the forage lands of the region, the biggest share is fodder grass (more than 80 $\%)$. Other $15 \%$ are maize, succulent feed and haylage. The total area of annual grass land is constantly decreasing. The gross output of crop production in the Kaliningrad region shows the prevalence of hay, annual grasses and perennial crops, feeding root vegetables (including sugar beets), maize, green feed and haylage.

Since 2000 , the gross output of crop production has not grown substantially (by $4.5 \%$ only), though its content has drastically changed. In 2000, it largely consisted of hay, but since 2009, the bulk of the output has been maize, green feed and haylage. The share of feeding root vegetables is still small despite their high crop capacity and the fact that climatic conditions of the region are favorable for their cultivation. The forage lands and the use of concentrated feeding stuff as well as the state of pastures and their management are of great importance for the development of fodder supply.

During the Soviet times, this work was done very effectively in the Kaliningrad region. It allowed to gain dairy and meat cattle productivity. In the 1990s, many farms refused to manage pastures, which led to the degradation of forage lands - they are overgrown with weeds and their amelioration system is destroyed. All these factors result in low productivity of dairy farming in the region.

\section{Conclusion}

The analysis of livestock development identifies factors that can stimulate its growth. However, the state of the livestock industry is still far from being adequate. Despite the growth in production output, which has been marked since 2010, the level of livestock development in small households in particular is still very low. Difficulties in fodder conservation, lack of modern technologies and the unsatisfactory state of this sector of agriculture the region have lead to low productivity of the agricultural industry. Boosting livestock development and improving the effectiveness of agriculture require measures of government support to the agricultural industry of the Kaliningrad region.

\section{References}

Federal State Statistics Service in the Kaliningrad region (2005). The Kaliningrad region in figures. A statistical report. Kaliningrad. Federal State Statistics Service in the Kaliningrad region (2006). The Kaliningrad region in figures. A statistical report. Kaliningrad. Federal State Statistics Service in the Kaliningrad region (2007). The results of the survey on the production of milk in private farms of the rural population. Kaliningrad.

Federal State Statistics Service in the Kaliningrad region (2007). The Kaliningrad region in figures. A statistical report. Kaliningrad. Federal State Statistics Service in the Kaliningrad region (2008). The Kaliningrad region in figures. A statistical report. Kaliningrad. Federal State Statistics Service in the Kaliningrad region (2009). The Kaliningrad region in figures. A statistical report. Kaliningrad. Federal State Statistics Service in the Kaliningrad region (2010). The Kaliningrad region in figures. A statistical report. Kaliningrad. Federal State Statistics Service in the Kaliningrad region (2010). Agriculture of the Kaliningrad region. A statistical report. Kaliningrad. Federal State Statistics Service in the Kaliningrad region (2011). The Kaliningrad region in figures. A statistical report. Kaliningrad. Federal State Statistics Service in the Kaliningrad region (2012). The Kaliningrad region in figures. A statistical report. Kaliningrad. Federal State Statistics Service in the Kaliningrad region (2012). Social and economic situation of the Kaliningrad region in 2011. Kaliningrad.

Federal State Statistics Service in the Kaliningrad region (2013). The Kaliningrad region in figures. A statistical report. Kaliningrad. Federal State Statistics Service in the Kaliningrad region (2014). The Kaliningrad region in figures. A statistical report. Kaliningrad. Federal State Statistics Service in the Kaliningrad region (2015). The Kaliningrad region in figures. A statistical report. Kaliningrad. 